\title{
Independent Community Archives: Challenging the Status Quo of Private and Public Archives
}

\author{
ANNE J. GILLILAND, PH.D. \\ Professor, Department of Information Studies, University of California, Los Angeles, United States of America, \\ Los Angeles, 212 GSE\&IS Building, Box 95120-1520, CA 951520, +1-310-206-9393 \\ e-mail: Gilliland@gseis.ucla.edu
}

TAMARA ŠTEFANAC, PH.D.

independent researcher, Croatia, Zagreb

e-mail: tamara.stefanac@gmail.com

Independent Community Archives: Challenging the Status Quo of Private and Public Archives

ABSTRACT

The community archives movement has emerged as a prominent, and often critical, presence within, and also outside the archival traditions and practices in North America and the United Kingdom. They can take many forms and often contest how both public and private archives in these regions have historically been understood, structured and operated. This paper first presents a brief review of some of the ways in which community archives have been framed in the archival literature. It then considers several questions regarding how such framings of community archives might challenge the status quo of private and public archives as currently defined and organized under the recently revised Croatian legislative framework and proposes a more conciliatory approach.

Archivi di comunità indipendenti: sfidare lo status quo degli archivi pubblici e privati

\section{SINTESI}

Il movimento di archivi di comunità è emerso come una presenza preminente, e spesso critica, all' interno ed anche all'esterno delle tradizioni e delle pratiche archivistiche nel Nord America e nel Regno Unito. Possono assumere molte forme, e spesso contestare come sia gli archivi pubblici che privati in queste regioni siano storicamente stati capiti, strutturati e gestiti. Questo lavoro presenta in primo luogo una breve rassegna di alcuni dei modi in cui gli archivi di comunità sono stati inquadrati nella letteratura archivistica. Vengono quindi analizzate alcune questioni relative al come tali inquadramenti degli archivi di comunità potrebbero sfidare lo status quo degli archivi pubblici e privati come attualmente definiti e organizzati sotto l'aspetto del quadro legislativo croato recentemente rivisto, e viene proposto un più approccio più conciliante.

Neodvisni arhivi skupnosti: izpodbijanje statusa quo zasebnih in javnih arhivov

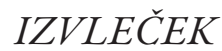

Gibanje arhivov skupnosti je vzniknilo znotraj z vidno in kritično prezenco, sicer pa zunaj arhivskih tradicij in praks v Severni Ameriki in Združenem kraljestvu. Javni in zasebni arhivi so lahko različnih oblik in se med seboj pogosto izpodbijajo, kako so bili zgodovinsko razumljeni, strukturirani in upravljani v omenjenih regijah. V prispevku je najprej predstavljen kratek pregled smestitve arhivovo skupnosti v arhivski literaturi. Nato je obravnavanih več vprašanj v zvezi s tem, kako bi takšna umestitev arhivov skupnosti lahko izpodbijala status quo zasebnih in javnih arhivov, kot je trenutno opredeljen in organiziran $v$ nedavno spremenjenem zakonodajnem okviru Hrvaške in predlaga bolj spravni pristop. 


\section{Introduction}

There are today, and historically have been, many methods of archiving the experiences, cultures and collective memory of different communities. For example, state archives may be charged with documenting legally-recognized minorities within their countries, or may reach out to emigrant and other ex-patriot groups; and university historical manuscript collections, museums, and local ethnological organizations may acquire primary materials relating to ethnic and other kinds of historical and contemporary communities. Multi-institutional and sometimes multi-national collaborations such as ICARUS encourage community self-documentation through the Topotheque and other initiatives. However, the so-called independent community archives movement, which has become prominent in North America and the UK over the past two decades, and which has become a central focus of the Community Informatics Research Network (CIRN) Conference held annually in Prato, Italy, has increasingly taken the form of a conceptual and organizational critique of traditional archival and other documentary institutions, structures, standards and practices. This critique extends not only to archives that are defined legally or institutionally as public but also to those that are private.

In this movement, a 'community' is self-defining around some common interest, characteristic or experience for example, sharing a particular ethnic, racial, gender, sexual, socio-economic, political, religious, occupational, artistic or other self-identity). The archives, or other forms of documentary, historical or memory initiative that the community might establish, are generated, organized, and made available as a result of the activities, needs and wishes of the community itself. Those who initiate and manage community archives are frequently community members themselves. They may not necessarily be qualified professional archivists and indeed it is their community knowledge, expertise and allegiance that may be the most valued. In other words, community archives are community-based in terms of their impetus, ethos, practices, and, often, funding support; and independent of state archival organizations and of systematic state or professional oversight or regulation. Many of these community archives have been established with the specific aims of redressing historical and contemporary marginalizations and inequities in how the experiences and collective memory of their communities are represented in mainstream historical or memory institutions, and providing the stimulus as well as support and documentation for local activist, and civil and human rights agendas (Sheffield, 2015).

The community archives movement appears to have much less traction in Central and Southeastern Europe, however, even though there are certainly entities in these regions that share characteristics with community archives in other parts of the world. Why might this be? Are traditional archival institutions and the legislative structures within which they operate in these regions less aware of the community archives movement and its increasing prominence elsewhere? Are they structurally less accommodating to such a movement or professionally unwilling to acknowledge or engage critically with this emerging challenge to traditional archival practices? Is there less theorization of archivistics occurring in these spaces that might provide legitimacy to the community archives movement and warrant for its recognition, and if so, what might be the implications of this for the development of the local archival profession? What might be the implications for continued growth in mutual understandings between how archivistics are developing in different regions of the world or for the creation and implementation of international standards? What beneficial opportunities might be being lost for partnerships between state and community archival entities?

It is beyond the scope of this particular paper to address all of these questions in depth in the contexts of the various countries represented at IIAS. However, in an effort to begin a conversation around these questions, the paper first presents a brief review of some of the ways in which independent community archives have been framed in recent archival literature. It then uses examples from the recently revised Croatian legislative framework to consider how such framings of community archives might challenge the status quo of private and public archives as currently defined and organized in accordance with state archives law and regulations.

\section{Characterizations of community archives in the research literature}

As already mentioned, community archives may take different forms, often appearing quite unlike traditional archives in structure, content and organization. The reasons for, and the initiators and locations of such initiatives have varied according to historical moments and contexts. Community archives' 
holdings may include a mix of archives, oral histories, visual materials, artefacts and publications that professional fields might otherwise separate and consign on the basis of format to archives, museums, libraries, oral history collections and so forth, or indeed might consider to have little collective scholarly value. Their value, however, derives precisely from their collectivity and multiple formats, as well as from their direct and immediate practical, political and affective relevance to the community in question. They may not be prepared to make their holdings available beyond community members, or may set their own requirements for wider access, use and reproduction. As such, community archives have consistently introduced new and often contested, approaches and debates to the archival profession (Gilliland, 2018), critically and creatively challenging professional norms and best practices relating to staff expertise, environmental conditions and archival practices, even the societal role and ethical conduct of archives.

Efforts over the past decade by archival scholars to understand the reasons behind the massive upsurge in community archives endeavours, the ways in which community archives conceive of and (re) present themselves, and how their activities, profile and aspirations have been facilitated by digital media and information and communications technologies, have examined a wide range of types of community archives and have extensively theorized their nature and role. Among the first to do so were English archival academics Andrew Flinn, Mary Stevens and Elizabeth Shepherd, who in 2009wrote of the "enormous number" of grassroots history and memory initiatives that had sprung up in the UK over the previous three or four decades. They argued that:

\begin{abstract}
"The impetus for such projects arose from a range of motivations but in general all were responding to the desire to document, record and preserve the identity and history of their own locality and community. Some custodians and creators of these collections remain suspicious of the mainstream archival profession and are determined to preserve their independence and autonomous voice by retaining direct ownership and physical custodianship of their collections, at least for the foreseeable future." (p. 71).
\end{abstract}

In a 2010 article, Flinn acknowledges the diverse roots and forms of community archives and history-making, but notes that "In many instances, the urge to collect archives and write histories is one felt by activists inspired by a political or cultural concern with documenting otherwise under-voiced or less visible communities and challenging the absences and biases in dominant historical narratives" (p.41). Gilliland and Flinn (2014) examine the differing trajectories of the community archives movement in the UK and US and point out that there are often differences not only between national contexts and cultures, but also between how the term 'community archives' is used by those theorizing the movement and by those actually involved in the activity, if the latter use the term at all. They argue that the terms 'community archives' and the notion of a 'community archives movement' have been largely imposed by archival academics and the mainstream archival profession as a way to refer to these grassroots community phenomena, while individual community archives often call themselves by whatever label (e.g., archives, library, museum, documentation centre) seems to be the most understandable by their own community and the most useful in terms of the alliances they can make and resources they can secure. Gilliland and Flinn also observe that the term 'community' can be problematic in the English language because of its multiple meanings and associations:

"Unease over the use of 'community' is common and relates to a lack of clear definition, its ubiq-
uitous use in government policy-speak and its associated potential for being used in an ill-defined
fashion by media and state bodies as a device for denoting the 'otherness' and 'separateness' of the
specific group in society being described as a community..., whose interests and concerns can be
therefore ignored as being not reflective of the majority of society." (2014)

As a result, these entities may instead be referred to as 'community-based', 'community-led' or 'community-centred', in an effort to emphasize that what distinguishes community archives and directly influences, collections, aims and objectives, structures and governance is their centring of community voices, experiences, needs, wants and priorities. In this respect, Gilliland's Voice, Identity, Activism (VIA) framework for community archives (2014) lays out three guiding principles:

1. The interests, needs and well-being of the community are central and paramount. Robust and recognized recordkeeping and archives are as critical to the empowerment and profile development of grass-roots, identity- and issue-based, and activist communities as they have traditionally been to high-power organizations and bureaucracies such as governments, businesses, religious organizations and academic institutions, even if their manifestations may not take on 
the same forms as those found in more 'mainstream' settings. They are, therefore, a fundamental component of social justice, civil rights, and democratic movements and have direct impact upon the lives and well-being of communities and their constituents.

2. Community records and heritage materials should not simply be approached by archives and collecting institutions that are external to the community as collectibles, 'rescue' or 'salvage' projects, or as means to diversify or 'round out' existing documentary sources. Instead, the place and meaning of community archives and their contents need to be clearly understood in any potential archival relationship between the community and an external collecting institution and a mutually beneficial partnership approach devised.

3. A community-centric framework for approaching archives and recordkeeping more generally recognizes that there are important and constantly evolving community interests, epistemologies, demographics and emotions that must be addressed in archival activities and that these will present challenges necessitating a re-thinking of 'mainstream' archival practices as well as heightened understanding of those of the communities in question.

As previously noted, several new archival concepts and ways of thinking about archival practice have emerged in the process of studying community archives. The work of US archival academic Michelle Caswell and her research team in particular have substantially advanced thinking about community archives based upon US experiences, promoting, for example, the applicability of the feminist ethic of radical empathy to community archives (Caswell - Cifor, 2016). Whereas much previous work has focused on how community archives tend to diverge from more traditional archival forms, ideas and practices, Caswell has also presented a survivor-centric theoretical framework for managing human rights archives based on lessons that mainstream archives might learn from five key principles in community archives discourse: participation, shared stewardship, multiplicity, archival activism, and reflexivity (2014).

\section{Community archives in the Croatian context}

As this brief review suggests, the majority of archival theorizing about community-based archiving has occurred in English-speaking countries that have a diversity of community archives and scholars in archivistics who have approached them as a subject of study. These are also Common Law countries where independent community documentation efforts have been a feature of the historical and cultural landscape for just about as long as the modern archival profession has existed. These countries tend to have more open-ended archival legal, regulatory or professional structures than those in Civil Law jurisdictions which also often have much older archival traditions (for example, the US has no archives law, state archives system, or required professional archival examination, although it does have extensive post-graduate education programs in archival science). The ability of community archives in these countries to serve as independent, critical and as necessary, oppositional voices to official narratives and historical institutions is also regarded as fundamental to their democracies.

In June 2018, Croatia passed a revised law regulating public and private archives. It offers a useful example of a Central/Southeastern European country with a complex archival regulatory and professional lineage when examining the transferability of community archives concepts and terminology into these regions. In Croatia, which became an independent republic in 1991 after breaking with the Socialist Federal Republic of Yugoslavia (SFRY), there is no accepted professional conception of a community archive as framed in the professional and research literature. There are also few scholars engaged with studying and theorizing such phenomena, and those who do mostly are not working within the state archival system or universities. And yet, entities with characteristics of community archives have increasingly emerged since Croatian independence (Gilliland - Štefanac, in press), thus begging some fundamental definitional, functional and structural questions about their status and nature within the Croatian archival landscape (Mokrović, 2014).

Significant new and linguistically nuanced archival terminology has been coined in English, a richly expressive language, as a result of the activities and theorization of community archives, but it is unclear how, if at all, such concepts and the words through which they are expressed might translate into other languages or to countries with very different archival experiences. Difficulties immediately arise when translating complex and socio-politically-contingent concepts from English into Croatian, a linguistically less rich minority language, but one where quite different professional concepts using similar 
terminology already exist. A direct translation of 'community archives' into Croatian would refer only to religious communities (of which there are many in Croatia, and several of which are quite ancient and hold important religious manuscript collections as well as community records). These are recognized by the state as communities and have always kept their own records in 'private archives' (although in public parlance the term 'religious archives' is often used to underscore that they are 'specialized archives', meaning that they are not part of official state archive system, but given their long tradition and importance in Croatian society these archives could indeed bear the label of special). In fact, a special statute on church archives was issued by the Yugoslav [Catholic] Bishops' Conference in 1973 to regulate procedures for church records and archives. While Communist ideology argues against 'private property' as it refers to industry and means of production and supports collective ownership and management, the concept of 'private archives' in the SFRY and still today in Croatia refers to the archives of foreign or domestic private but legally established organizations such as universities, businesses and banks where the records are not part of the general public record (Hedbeli, 2007). In the SFRY, personal belongings were considered to be private property, but only to a certain extent. Private archives were addressed in article 13 of the 1978 law on the protection of archival material and archives, which stated that, "Civil legal entities and citizens may keep and protect their own archival material" (Official Gazette No. 25, 1978). Articles 28 to 32 of the same law, however, required those private entities to keep their material safe, to allow research on their material and also to allow archivists from the State Archives to film their records. These regulations are repeated in today's legislative framework (with a few differences, mostly related to digital developments). The term 'osobni fond' is still used in Croatia to refer to personal papers created or accumulated by a creator in their personal capacity. However clauses were added to the Archives Law of 1997 stating that under the Republic of Croatia's Constitution, objects of particular cultural, historical, economic or ecological importance, such as certain personal papers or private archives, if defined by the law to be of interest for the nation, enjoy its special protection (Hedbeli, 2007). The rubric of 'special archives' also does not apply, since it is the term applied to public archives that have a special access regime, such as Diplomatic Archives, Military Archives, the Archives of the Central Committee of the Communist Party, or the Secret Police Archives.

'Specijalizirani arhivi'(specialized archives) as well as 'privatni arhivi' (private archives), which may be founded with the permission of the Ministry of Culture through a procedure designated by state law and regulations, would both be candidates for existing rubrics to use for community archiving initiatives:

"Article 42. Specialized and private archives (university archives, business archives, church ar-
chives, bank archives etc.) may collect and preserve archival and current records created through
the activity of their founders and other domestic corporate bodies or persons. Specialized archives
established for the protection, processing and consultation of public records may be established
based on the approval and a decree on the division of responsibilities referring to archives from
the Article 3 Paragraph 2 of this Act as ruled by the Minister of culture." (http://zagreb.arhiv.hr/
en/hr/pdfIZakon\%20eng.pdf)

The regulations require, however, that the archives meet specified storage conditions and equipment needs, are able to protect and process archival materials appropriately, and have the requisite numbers and levels of archival professionals. An example would be the Croatian Memorial-documentation Centre for the Homeland War, which is considered to be 'javna znanstvena ustanova' (a public scholarly institution) and a 'specijalizirani arhiv od interesa za republiku Hrvatsku' ('specialized archive in the interests of the Republic of Croatia'). The Archive of Serbs in Croatia also has the status of both a specialized and a private archive. The Hrvatski školski muzej (Croatian School Museum) provides a different kind of example - the museum was founded according to the regular processes, but they held a considerable amount of archival materials and so they hired an archivist. The archivist was required to pass the state certification examination after which she initiated the procedure to have the archival materials designated as a specialized archive situated within the museum.

The politics of linguistic divergences between Serbo-Croatian, which was the official language of the SFRY, and the post-independence Croatian language present an added consideration. This issue was illustrated when a Serb archivist who is familiar with American community archives proposed 'društvene arhive' or else 'nezavisni arhivi' as possible new terms that might be used. When presented to many Croats, however, 'društvene arhive' ('social archives' or 'archives of society') may smack of former Socialist and Serbian terminology and is, therefore, both confusing and hard to accept. 'Nezavisni arhivi' ('independent archives') on the other hand, to use a term that would be more in line with 
that used in the UK, raises other concerns because there is no structural capacity for an independent archive to exist as a recognized entity under Croatian law. Such an archive can be registered as a private or specialized archive, but the term 'independent' suggests actual independence which in reality doesn't exist for at least two reasons: public funding (distributed by state and local authorities), and oversight by the State Archives.

This raises an overarching factor - regulatory structures and professional understandings govern archival institutions and practices and define archival materials in Croatia. In Civil Law jurisdictions, and especially in the former SFRY and Eastern bloc countries, 'archives laws' (and parallel 'museum laws'), as well as regulations setting out implementation procedures remain common (Grimsted Kennedy, 1982, 1992, 1993). After its founding in 1945, the SFRY established a national federal archives system centered in Belgrade, with central state archives located in the capitals of each of the Yugoslav republics and then multiple regional state archives within each republic. With the break-up of the SFRY, each republic's central state archive became a national archive that administers the regional archives, with jurisdiction under its own national Archives Law to set the conditions for the management of all registered archives and archival materials in the country. The Yugoslav Archives Law sought not only to safeguard the cultural heritage of the new nation against loss, theft, damage and so forth, as do such laws in many nations, but also to preserve and promote Communist ideology through the preservation of records that could be used by journalists and scholars who would generate a new body of published history. The Yugoslav Archives Law became defunct after Croatian independence and a new Croatian Archives Law was passed in 1997 (Ketelaar, 2008). There was some general legal reframing when Croatia entered the European Union in 2013 in order to meet EU directives, and the law underwent a more substantive revision in 2018. In many respects the archival structures that the Croatian law mandates, and the associated regulations issued by the Ministry of Culture that implement those mandates, do not significantly diverge, however, from those imposed under Yugoslavian law even though the underlying political ideologies are completely different.

The 2018 revision of the law requires the State Archives to create a Register of owners or holders of private archival material that lists all private archival material that has special import for history, science or culture. It should also be noted, of course, that many articles of the Archives Law, such as the requirement to register 'cultural goods' (archival materials) with the State Archives, or to obtain a permit to move them out of the country are not specific to Communist or Socialist European countries but are common in archival laws in many Western European countries also. State archivists are also required to report to the state any knowledge they have of the existence of archival materials in any location. The Archives and Museum Laws distinguish between archives and museum materials and mandate different archival or curatorial practices for each, but diversity in types of material held is one of the aspects that have typified community archives. Under the laws, materials that might straddle both kinds of institutions should be allocated to one or the other. This means that a community archive should be registered as either an archive or a museum, with no possibility of straddling both, or indeed, other forms of heritage or memory institutions such as libraries (Štefanac, 2017). Institutions founded through these procedures are officially acknowledged by the State Archives, while other initiatives that might be more conceptually or structurally fluid do not fit into this framework, or choose not to fit, even though in Croatian contemporary professional discussions the concept of 'total archives' as conceived in the Common Law Canadian archival tradition (Millar, 1998) is perceived as the goal to which archival theory and practice should aspire. In the draft of the new Law on Archives that was presented during its first reading in the Croatian Parliament it was stated that:

\begin{abstract}
"The system of protection for public archival material is based on comprehensiveness and includes all public documentary and archival material. Unlike that, the system of protection for private archival material should be directed towards that material for which public interest has been established, based on which the owners [of the material] are assigned certain responsibilities and their rights to freely manage their own material are partly restricted." (http://www.sabor.hr/ prijedlog-zakona-o-arhivskom-gradivu-i-arhivima-pr)
\end{abstract}

This explanation of the concept of private archival material indicates how conceiving of community archives as private archives could be problematic, and indeed how the law leaves little room for community archives that philosophically or politically disagree with or reject legal and professional archival structures movement. 
If a community archive were to be initiated that decided not to go through the official registration process, likely nothing would happen to it, but it would not be treated as an institution, and the persons developing it would not be perceived as a community or indeed as any kind of archivist. It would also have to apply for state or local funding through procedures designated for NGOs and not through the procedures established for archives or museums. For a community archivist wishing to be so acknowledged (although again those in more activist or oppositional community archives might not because they wish to maintain their community-centricity and distinguish themselves, their archives and their practices from those of the state), the ability to obtain professional recognition is also in question. Current regulations prescribe that every person employed in the state archive system has to pass a state examination administered by the Croatian State Archive under the authority of the Ministry of Culture. Under the revised law open questions remain as to whether community archivists will be recognized as professionals and will be allowed to apply to take the state examination. The more meta-level questions, perhaps, are whether, if community archives are independent entities, they can also be considered to be private archives given the legal and regulatory conditions under which private archives are conceived and operate? What if they reject professional standards and best practices and even professional expertise as not serving the best interests of their own community? What if their autonomous states and stances lead them to operate without a stable budget and the ability to guarantee the ongoing preservation of their holdings? The latter are common phenomena within the community archives movement elsewhere, and in both the US and UK have engendered critical distrust on both sides in each others' ability to act as reliable, ethical and robust stewards for archival materials and to safeguard the interests of their creators and the subjects of their holdings. At the same time, however, it is increasingly recognized that there are important opportunities for community archives to be complementary to the official archival system or even to work in partnership with them (Gilliland - McKemmish, 2014).

One final question that might be asked and that has particular significance to some countries in these regions is: If community archives play an important role in promoting civil and human rights, do they have particular and distinctive roles in civil society movements in formerly non-democratic states (Gilliland and Štefanac, in press)? The community archives movement of recent decades has underscored the importance of archives to the protection of human rights around the globe. In the Croatian context these efforts are closely connected with civil society organizations that emphasize the act of documenting as one of the main efforts of their operation. Serving as such kinds of documentation centres or self-declared archives, especially for predominately cultural, artistic or community endeavours, necessarily engages a notion of private property. Article 24 of the 2018 Law on Archival Material and Archives also obligatesowners and holders of archival and documentary material to notify the state or regional archive about their possession of material, to keep material safe, to list and process the material, and allow to allow a representative from the state or regional archive to examine the material and make security copies if needed. It would seem that in this way private property easily once again can come under public control, if the state archivists decide that it is of public interest. Article 25 mandates that if such important private material is not kept in conditions that are prescribed by the state archive system it can be physically removed from the custody of the private owner. As such, the basic tenets of a community archive as operating within the best interests of its own community and functioning autonomously of the state, can be subverted and the idea of categorizing them as private archives becomes a liability rather than a protection. Although what might happen to 'distressed' community archives that are unable to continue to support themselves financially or to care for their holdings is certainly an important consideration (Wiśniewska, 2015) the notion of better protection for important archival material through conformity with state-required archival practices (one of the fundamental assumptions that community archives often contest) can easily be turned in the opposite direction with apolitical or societal shift that prefers some historical narratives over others or that imposes constraints on civil or human rights. The self-determination, voice, and protection of private archival materials that community archives seek to promote might instead be better achieved through more networking and deeper and respectful mutual understanding among all those who serve as stewards for the nation's archives, leading to offers of help and partnerships rather than control, and even to modified, more open-ended practices within state archival institutions. 
Anne J. GILLILAND - Tamara ŠTEFANAC: Independent Community Archives: Challenging the Status Quo of Private and Public Archives, 207-215

\section{Sources}

Michelle CASWELL, Toward a survivor-centered approach to records documenting human rights abuse: Lessons from community archives, "Archival Science”, 14(2014), pp. 307-322.

Michelle CASWELL - Marika CIFOR, From human rights to feminist ethics: Radical empathy in the archives, "Archivaria”, 81(Spring 2016), https://archivaria.ca/index.php/archivaria/article/view/13557 (last visit 29 $9^{\text {th }} \mathrm{July}$, 2018).

Andrew FLINN, Independent community archives and community-generated content: 'Writing, saving and sharing our histories', "Convergence: The International Journal of Research into New Media Technologies”, 16(2010) n. 1 , pp. 39-51.

Andrew FLINN - Mary STEVENS - Elizabeth SHEPHERD, Whose memories, whose archives? Independent community archives, autonomy and the mainstream, "Archival Science", 9(2009), pp. 71-86.

Anne J.GILLILAND, Conceptualizing Twenty-first-century Archives, Chicago, 2014.

Anne J. GILLILAND, Trust matters, "Provenance” (2018).

Anne J. GILLILAND - Andrew FLINN, The wonderful and frightening world of community archives: what are we really talking about? In Proceedings of CIRN 2013 Community Informatics Conference: 'Nexus, Confluence, and Difference: Community Archives meets Community Informatics,' Prato, 28-30 October 2013, https://www.monash.edu/_data/assets/pdf_file/0007/920626/gilliland_flinn_keynote.pdf(last visit 29 $9^{\text {th }}$ July, 2018).

Anne J. GILLILAND - Sue MCKEMMISH, The role of participatory archives in furthering human rights, reconciliation and recovery, "Atlanti", 24(2014), pp. 79-88.

Anne J. GILLILAND - Tamara ŠTEFANAC, Post-x: Community-based archiving in Croatia. In Community Archives, Volume Two: Sustaining Memory, Andrew Flinn and Jeannette Bastian, eds, London, (in press).

Patricia Grimsted KENNEDY, Beyond Perestroika: Soviet-area archives after the August coup, "The American Archivist", 55(Winter 1992), n. 1, pp. 94-124.

Patricia Grimsted KENNEDY, Lenin's Archival Decree of 1918: The Bolshevik legacy for Soviet archival theory and practice, “The American Archivist”, 45(Fall 1982), n. 4, p. 433.

Patricia Grimsted KENNEDY, Russian archives in transition: Caught between political crossfire and economic crisis, “The American Archivist”, 56(1993), pp. 614-662.

ŽivanaHEĐBELI, Privatno arhivsko gradivo u Hrvatskoji inicijativane vladinih organizacija, "ATLANTI", 17(2007), nn. 1-2, pp. 223-232, http://www.iias-trieste-maribor.eu/fileadmin/atti/2007/Hedbeli.pdf (last visit $29^{\text {th }}$ July, 2018).

ICARUS, Topothek: Unsere Geschichte, unserArchiv, https://www.topothek.at/en/ (last visit 29 ${ }^{\text {th }}$ July, 2018).

Eric KETELAAR, Hrvatsko arhivsko zakonodavstvo i praksa: Između sna i jave, “Arhivski vjesnik”, 51(2008), pp. 129-148, http://hrcak.srce.hr/29489?lang=hr (last visit 29 ${ }^{\text {th }}$ July, 2018).

Laura MILLAR, Discharging our debt: The evolution of the total archives concept in English Canada, "Archivaria”, 46(Fall,1998), https://archivaria.ca/index.php/archivaria/article/view/12677 (last visit 29 ${ }^{\text {th }}$ July, 2018).

Nikola MOKROVIĆ, Community Archives in Croatia, (2014), http://kreuz-krzyz.pl/as/as_img/uploaded/ NikolaMokrovic.pdf (last visit 29 ${ }^{\text {th }}$ July, 2018).

REPUBLIC OF CROATIA, The Law on Archival Material and Archives, Official Gazette, (2018), n. 61, https:// narodne-novine.nn.hr/clanci/sluzbeni/2018_07_61_1265.html (last visit 29 $9^{\text {th }}$ July, 2018).

Rebecca SHEFFIELD, The Emergence, Development and Survival of Four Lesbian and Gay Archives, doctoral dissertation, University of Toronto, 2015.

Tamara ŠTEFANAC, The Conceptualization of Archival Materials Held in Museums, doctoral thesis, University of Zadar, 2017.

USC Shoah Foundation Visual History Archive, https://sfi.usc.edu/vha (last visit 29 $9^{\text {th }}$ July, 2018).

Magdalena WIŚNIEWSKA, Digital community archives - selected examples, "Archiwa-Kancelarie-Zbiory" 6(2015), n. 8, pp. 222-236, http://dx.doi.org/10.12775/AKZ.2015.008 (last visit $1^{\text {st }}$ August, 2018). 
Anne J. GILLILAND - Tamara ŠTEFANAC: Independent Community Archives: Challenging the Status Quo of Private and Public Archives, 207-215

\begin{abstract}
SUMMARY
Community archives are independent grassroots entities that document the experiences of 'communities' or groups that share a particular self-identity. The so-called community archives movement has significantly and critically challenged the archival traditions in the US and UK but appears to have much less traction in Central and Southeastern Europe. Arguably this is because a strong presence of community archives is dependent not only on societal and cultural factors but also on the legislative and regulatory frameworks within which archives and other memory institutions operate. This paper addresses the space available for community archives in post-socialist Croatia where archival concepts, institutions and practices operate within a framework that is closely defined by state archives legislation and regulation. In this context, since there is no accommodation for community archives as understood elsewhere, an entity with the characteristics of a community archive might be placed under the legislative concept of private archive and its operation strictly regulated. This, however, is the antithesis of the concept of community archives that has been delineated by archival theoreticians and practically instantiated by communities in other regions over the past two decades. Among the defining characteristics of community archives are autonomy of action and independence from state control. A designation of private archive instead results in private property and individual community voice becoming less important than broader public interest. Although this designation might be intended to protect heritage, ultimately it also diminishes the national archival heritage and archivistics. The self-determination, voice, and protection of private archival materials that community archives seek to promote might instead be better achieved through more networking and deeper and respectful mutual understanding among all those who serve as stewards for the nation's archives, leading to offers of help and partnerships rather than control, and even to modified, more open-ended practices within state archival institutions.
\end{abstract}

Typology: 1.01 Original scientific article

Submission date: 05.08 .2018

Acceptance date: 08.08.2018 